\title{
Learning design for teacher professional development
}

\author{
Muriel Garreta-Domingo ${ }^{1 *}$, Peter B. Sloep², Davinia Hernández-Leo ${ }^{1}$ and Yishay Mor ${ }^{3}$
}

\author{
* Correspondence: \\ murielgd@gmail.com \\ ${ }^{1}$ Universitat Pompeu Fabra, \\ Barcelona, Spain \\ Full list of author information is \\ available at the end of the article
}

Keywords: Learning-design; Professional development; Teachers; Teaching

Even though they may never describe themselves in such terms, teachers have always been designers of learning experiences, whether 'performing' in the lecture theatre and classroom or writing handouts, syllabi or textbooks. Acting in the rather stable learning ecosystem of the classrooms and lecture halls of the past, there was no need to reflect upon their role as designers, indeed teachers saw themselves predominantly as bearers and transmitters of the values and knowledge that our cultures are made of. However, things have changed. Knowledge and values still matter, there can be no doubt about that. But one has come to conclude that a lot of learning takes place outside the classroom and lecture theatre. Also, the pace of societal change is ever increasing, making it a necessity to keep learning after formal schooling, informally at home or at the workplace. And perhaps most importantly, technology has entered our daily lives to an unprecedented degree. So we need to learn about technology as a subject, but also and in the present context more relevant, we need to figure out how technology can allow us to learn more effectively, more efficiently and, if at all possible, more agreeably. These changes pose many challenges, particularly for those who have made fostering the learning of others their call teachers, that is. The present-day consensus seems to be that teachers can only address these challenges if they adopt a designer's mindset, if they start seeing themselves as designers of learning experiences for others. Transforming oneself from an information (and values) conduit into a learning designer (perhaps even co-designer) is a tall order. Teachers are in the midst of going through that transition, be they in-service teachers who need to change their prevailing practices or pre-service teachers who need to learn the tricks of the new trade.

To this special issue a total of 11 papers was submitted. Five of them were deemed unsuitable in regards the topic, 2 of them were rejected after peer review; consequently, the issue counts four articles that all in their own way discuss aspects of the transformation of 'traditional' teachers to 'modern' learning designers.

The paper by Gachago, Morkel, Hitge, van Zyl, and Ivala (Developing eLearning champions: a design thinking approach (https://educationaltechnologyjournal.springeropen.com/articles/10.1186/s41239-017-0068-8) - published on July 19th 2017) takes an analytical stance. Acknowledging the need for a transition and being aware of its vastness, the authors attempt to describe and analyse what it takes to be a learning

(c) The Author(s). 2017 Open Access This article is distributed under the terms of the Creative Commons Attribution 4.0 International License (http://creativecommons.org/licenses/by/4.0/), which permits unrestricted use, distribution, and reproduction in any medium, provided you give appropriate credit to the original author(s) and the source, provide a link to the Creative Commons license, and indicate if changes were made. 
designer, particularly one who makes full use of modern technologies. Following as a lead the mindset of those who readily adopt technological innovations, they identify eLearning champions and analyse their mindset. Based on interviews with various eLearning champions, whom their colleagues have identified as such, they assemble a list of seven different elements that typify the eLearning champion. Among them feature such characteristics as a willingness to collaborate and be generous, empathy with the learner, and the ability to reflect yet be resilient.

Having the right mindset may be a necessary condition for being able to design learning experiences, it obviously is not a sufficient one. How can people with a design mindset be supported actually to come up with learning designs that fit a particular learning situation at hand? The next two papers address this question from two different vantage points, that of in-service teaching professionals and of pre-service teachers.

Chounta, Manske, and Hoppe ("From Making to Learning": Introducing Dev Camps as an educational paradigm for Re-inventing Project-based Learning (https://educationaltechnologyjournal.springeropen.com/articles/10.1186/s41239-017-0061-2) - published on September 1st 2017) take the so-called maker movement as their focal point: technology-supported communities that share ideas but, more importantly, realise them through projects. Transferred to a learning situation, such communities provide opportunities for forms of project-based and experiential learning in technologyrich contexts. The authors dub these communities Dev Camps, to emphasise the development aspect. Dev Camps, the authors claim, breed twenty-first century skills. But can they be used to innovate traditional formal learning? The authors convincingly argue they can and indeed should, with the role of the teacher becoming that of a process designer.

Papanikolaou, Makri and Roussos (Learning design as a vehicle for developing TPACK in blended teacher training on technology enhanced learning (https://educationaltechnologyjournal.springeropen.com/articles/10.1186/s41239-017-0072-z) - published on September 18th 2017) focus on pre-service teacher training. Their starting point is the 'age-old' problem of integrating technology in learning. All too often, or perhaps usually, content knowledge, pedagogical knowledge and technological knowledge are taught as separate items and it is left to the students (prospective teachers) to integrate this into a whole. This is notoriously difficult, if not impossible. So their solution is to employ the TPACK-framework to achieve integration and to use Communities of Inquiry as the mechanism to foster integration. This seems to work, in particular with respect to the integration of the three types of knowledge. However, it became also apparent that the CoI's did not act as a particularly powerful mechanism to foster knowledge building.

The final paper by Hermans, Sloep, and Kreijns (Teacher professional development in the contexts of teaching English pronunciation (https://educationaltechnologyjournal.springeropen.com/articles/10.1186/s41239-017-0059-9) - published on August 17th 2017) breaks away from the optimism that the first three papers radiate. It does not argue from design principles but tests in a 'live' situation the effectiveness of a particular professional development programme. The programme is about improving the English pronunciation skills of Dutch secondary school children. In-service secondary school teachers are asked to adopt this programme and report on their experiences working with it. First, the pronunciation competencies of the students improve, so in 
that sense the programme works. However, many teachers who participated complained they had too little time to be involved in these kinds of innovations, effectively showing their resistance to be involved in design work. Indeed, quite a few dropped out and gave 'lack of time' as their reason for doing so. This poses the question of whether we learning researchers and learning policy makers too easily assume that teachers are intrinsically motivated to engage in the transition from conduit to designers.

Of necessity these four papers only address a tiny bit of a vast number of aspects that make up the transformation from knowledge and value conduit into designer of learning experiences. How could it be otherwise, given the enormity of the challenges before us? Yet, we hope that these papers contribute some valuable insights that give pause for thought to researchers, policy makers and teachers alike.

Finally, we would like to thank the various reviewers for their valuable help with selecting and improving the papers in the special issue.

Authors' contributions

All authors read and approved the final manuscript.

Author details

${ }^{1}$ Universitat Pompeu Fabra, Barcelona, Spain. ${ }^{2}$ Open University of the Netherlands, Heerlen, The Netherlands. ${ }^{3}$ Levinsky College of Education, Tel Aviv, Israel.

Received: 21 September 2017 Accepted: 22 September 2017

Published online: 05 October 2017

Submit your manuscript to a SpringerOpen ${ }^{\circ}$ journal and benefit from:

- Convenient online submission

- Rigorous peer review

- Open access: articles freely available online

- High visibility within the field

- Retaining the copyright to your article

Submit your next manuscript at $>$ springeropen.com 